\title{
The Built Environment and its Impact on Transit based Transportation Users Walking Activity in Semarang, Indonesia
}

\author{
Anita Ratnasari Rakhmatulloh ${ }^{1 *}$, Diah Intan Kusumo Dewi ${ }^{1}$ and Dinar Mutiara \\ Kusumo Nugraheni ${ }^{2}$ \\ ${ }^{1}$ Department of Urban and Regional Planning, Faculty of Engineering, Diponegoro University, Semarang, \\ Prof. Soedarto, Tembalang, Semarang 50275, Indonesia \\ ${ }^{2}$ Department of Computer Science, Faculty of Science and Mathematics, Diponegoro University, Semarang, \\ Prof. Soedarto, Tembalang, Semarang 50275, Indonesia
}

\begin{abstract}
The increase in mobility rate due to the current rise in population has become a challenge in urban development. This led to the development of pedestrian walkways, which are integrated with transit-based transportation, to minimize problems due to the high level of mobility of the urban population. According to some experts, environmental conditions are one of the main factors capable of affecting pedestrians' frequency. Therefore, this study explores the effect of the built environment, such as density, diversity, and design, on the pedestrian frequency of the Bus Trans Semarang passengers. Data were collected from 9 corridors, consisting of 447 bus stops, directly connected to the pedestrian walkways, as one of the feeders for transit-based transportation facilities. The analysis method used for each variable was the formulation technique, with data simulated using various applications, such as ArcGIS. The linear regression partial t-test model was also analyzed using SPSS, with the effect of pedestrian frequency on dependent variables determined, using the built environment elements (independent variable). The results showed a positive significance between the diversity variable and pedestrians' frequency along the Bus

ARTICLE INFO

Article history:

Received: 16 November 2020

Accepted: 10 February 2021

Published: 30 April 2021

DOI: https://doi.org/10.47836/pjst.29.2.05

Trans Semarang corridors. Furthermore, the land that varies with the dominance of commercial and educational area has the highest attraction features that affects a person's frequency to walk.
\end{abstract}

$\overline{\text { E-mail addresses: }}$

anita.ratnasari.r@gmail.com (Anita Ratnasari Rakhmatulloh)

diah.intan@pwk.undip.ac.id (Diah Intan Kusumo Dewi)

dinar.mutiara@live.undip.ac.id (Dinar Mutiara Kusumo

Nugraheni)

* Corresponding author
Keywords: Built environment, pedestrian walkways, transit-based transportation 


\section{INTRODUCTION}

The development of a transit-based transportation system is intensively carried out as an alternative means of private transportation to overcoming population growth in various countries. According to Makarova et al. (2017), the Asian region is generally known for its unhealthy transportation system, which causes various problems, such as congestion, air pollution, and sprawl-related issues (Makarova et al., 2017). Therefore, to overcome this, the World Health Organization (WHO) encourages countries to implement sustainable transportation systems that focus on safe, efficient, accessible, affordable, inclusive, green, and healthy transportational mobility.

A Transit-Oriented Development (TOD) is a form of sustainable transportation that emphasizes integrating urban spatial design to unite people, activities, buildings, and public spaces through connectivity, accessible by walking (ITDP, 2017). Increasing walking intensity (walkability) is considered part of the effective solutions in overcoming unhealthy transportation because it minimizes congestion, increases environmental sustainability, encourages physical activity, improves public health, and enhances urban settlements' appropriateness (Blanco \& Alberti, 2009). The pedestrian walkways, commonly referred to as a sidewalk in a transit-based transportation system, is a facility feeder that connects a transit centre with other activity functions (Hu et al., 2013). However, the lack of optimal pedestrian walkways is a challenge for establishing a sustainable transportation system in several countries.

Various studies suggested that the optimization of pedestrian walkways, such as the completeness of design components, an attractive, safe, and comfortable city shape increases residents' tendency to walk to a destination (Özbil et al., 2015). Furthermore, the developments of a land-use planning, and urban design are crucial in increasing pedestrian activity in cities (Timmermans, 2009). However, research on the relationship between the conditions of the built environment, and walking tendency in the transit-based transportation system is rare. Various parties have been inclined to focus on increasing the transportation system's capacity, without observing how the developments affect the environment. Therefore, the development of a new transportation system is linear with the uneven distribution of building density and land-use management, thereby leading to inadequate functioning of several pedestrian walkways.

The built-environment is a transit-based transportation system commonly found in European countries. The initial milestone associated with this technique was first carried out by Cervero \& Kockelman (1997) in the European countries to welcome new urbanism concepts. According to them, the built environment means physical features of the urban landscape (i.e., alterations to the natural landscape). These authors formulate three main components to assess the built environment from the same source, namely density, diversity, and design. 
The density is defined as the component produced by observing population frequency per household and building quality per area (Cervero \& Kockelman, 1997; Monteiro \& Campos, 2012; Zhang et al., 2016). Furthermore, this research and the pedestrian activity in previous studies observed that the areas with a high-density level are associated with walking (Oktaviani et al., 2020). A study carried out by Duduta (2013) developed indicators for assessing density components in constructing measurements, which are properly related to building height or the Floor Area Ratio (FAR) analysis method. The study takes a minimum distance of $200 \mathrm{~m}$ from the stop point, which was recorded, and divided into three categories of level assessment, namely low (1-2 floors), medium (3-8 floors), and high ( $>8$ floors) densities.

The diversity component is represented as a land-use balancing index used to compare the ratio of residential and non-residential (commercial) areas. According to Sung et al. (2013), the level of balancing land-use in an area rises, the activities of pedestrians relatively increased. Furthermore, by simplifying Cervero and Kockelman (1997) research, the diversity component emphasizes the calculation model of residential and non-residential land area ratios, which in this case, is measured by the balancing index formula (Sung et al., 2013). The diversity variable analysis results show the patterns of land use and its changes due to population mobility. Several studies, such as those carried out by Cervero, found that the effects of diversity have long been ignored.

The design component is part of the features referring to the assessment of pedestrian walkways and its integration with the road network system (Dixon, 1996; Munshi, 2016). Similar to diversity, the effects of design also have long been ignored in built environment analysis. However, the design component's measurement is more complicated than density and diversity, with a system of assessing pedestrian walkway completeness elements adjusted to environmental conditions (Zhang et al., 2016). Therefore, this study summarized the design indicators needed to identify the appropriate pedestrian walkways at the research location. This includes the lane width, route count, road intersection number, the presence of ramps, bridges, zebra crossings, and the completeness of street furniture.

The country context plays an essential role in ascertaining the built environment assessment of pedestrian activities. The biggest question that emerged from previous research is whether the context of the European region's built environment is similar to the Asian zone. Furthermore, a research in downtown Montreal, Canada showed that the components of the built environment, density (population, number of jobs, schools, and bus stops), diversity (commercial land use), and design (percentage of main arteries, average length of roads), affected pedestrian activity (Miranda-Morenoa et al., 2011). This city's position in Canada is a provincial capital not included in the national central area. It is observed to be a part of the cities located in developed countries. In this location, the problem encountered was a lack of pedestrians' security on the walkways. However, 
this location had a complete pedestrian walkways element, surrounding skyscrapers. As a four-season country, the provision of vegetation along the pedestrian walkways in the city is designed to suit seasonal conditions. This is because the designs that adapt to climate change and periods are being intensified to create sustainable urban life.

The discussion of the built environment, on pedestrian walkways in developing countries, for example, the transit area in Bangkok, Thailand, was developed from an interplay between people's tendency to walk and the diversity of land-use around the transit area (Townsend \& Zacharias, 2010). The walkways condition in Bangkok, Thailand, is associated with air pollution and lack of sidewalks (Townsend \& Zacharias, 2010; Chalermpong, 2007). Therefore, from this study, it is obtained that the development of commercial, retail, and residential land is relatively high around the transit centre, which shows that the influence of diversity is high on pedestrian movement patterns.

The research carried out in other Asian regions, such as Beijing, China, obtained different results. According to Zhao et al. (2018), the findings on the built environment at the environmental-scale transit centres in Beijing, show that the density component plays a substantial role in influencing pedestrian activities. The study showed that the pedestrian walkway components in Indonesia was complete compared to those in Bangkok. Also, the influence of the vertical building construction policy in the central area of Beijing City is the basis for forming a compact area, with relatively close distances between buildings. Based on that statement, the density of the built environment in this area influences a person's inclination to walk. Therefore, the geographic characteristics with the research's scope carried out in Bangkok and Beijing relatively similar. This is because they are often conducted in locations with relatively flat homogeneous topography, using city-scale research coverage.

Semarang is one of the major cities in Indonesia, located in Central Java Province. The city intensively plans to develop a Transit Oriented Development (TOD) system, accommodate the community's mobility needs, and create a sustainable transportation channel. The requirement needed for the development of the TOD system in this city is the Bus Trans Semarang. The relationship between the built environment and pedestrian activities in the central transit area, along the Bus Trans Semarang corridor, seems interesting because it covers the city centre area with a diverse topography in its surroundings. The problem of pedestrian walkways provision in Semarang City is the same as that of Bangkok, which is associated with pollution related-issues, and lack of sidewalks. Based on further data, it was observed that approximately $88 \%$ of Bus Trans Semarang passengers walked to or from the bus stops (Purwanto \& Manullang, 2018). This result is certainly in contrast to the lack of pedestrian walkways provision in the city of Semarang, which then causes a gap between availability and demand. 
Policies regarding land-use, regulated by City Territory Section (CTS), indicated that Semarang City's use is very diverse. Furthermore, the absence of a firm policy on building construction efforts has led to a high sprawl level in this area. Therefore, this study aims to ascertain the best-built environment model, which affects a person's tendency to walk along the Bus Trans Semarang corridor, from the city centre to the suburbs. It also complements previous research that only focused on density conditions in the built environment analysis. This research is further accompanied with a question, such as, 'Do the built environment components affect the pedestrian activity of transit-based transportation users in Semarang City?'

\section{METHODS}

\section{Semarang Study Area}

Semarang City is one of the metropolitan cities in Indonesia, located in Central Java Province, with a population of 1.79 million people. According to the data obtained from the Semarang City Statistics Centre in 2019, the population of this area keeps increasing by $50 \%$ yearly, accompanied by the provision of a non-optimal public transportation system. This location is one of the pilot project for Bus Rapid Transit (BRT) development in Indonesia, with the provision of Bus Trans Semarang in 2009, to help improve the quality of transportation system (SuaraMerdeka, 2015).

Therefore, this research covers all Bus Trans Semarang routes, consisting of, Corridors I, II, IIIA, IIIB, IV, V, VI, VII, and VIII, as shown in Figure 1. According to Kim et al. (2018), two methods are used to measure the built environment, based on the area's scope, namely, the street level of $50 \mathrm{~m}$ and the neighborhood position at a maximum radius of $400 \mathrm{~m}$, from the observation point. The data showed that the maximum distance for walking in Semarang City was only 200m-250m between destination locations (Purwanto \& Manullang, 2018). Therefore, sampling of the observation area, using the neighbourhood level method, with a radius of $200 \mathrm{~m}$ from the right and left of the road was carried out in this research.

In this study, the entire Bus Trans Semarang corridor has 596 bus-stops, scattered from the city centre to the suburbs, while also connecting various important land-uses, such as terminals, government areas, education fields, and many more, as shown in Table 1. Data from the Semarang City Transportation Office in 2018 showed a significant increase in Bus Trans Semarang passengers from 2010-2018. The total number of passengers between 2010 and 2018 were 369,326 and 10,210,296, respectively. Furthermore, the largest contributor for pedestrians in this study was Corridor I, which had massive bus-stops and fleets compared to the other eight corridors. Based on the data collected from the field observations, pedestrian activities along the Bus Trans Semarang corridor were dominated by school, work, and recreational activities. City centre areas such as Corridors I, II, and IV, had more massive pedestrian activities than other zones. 


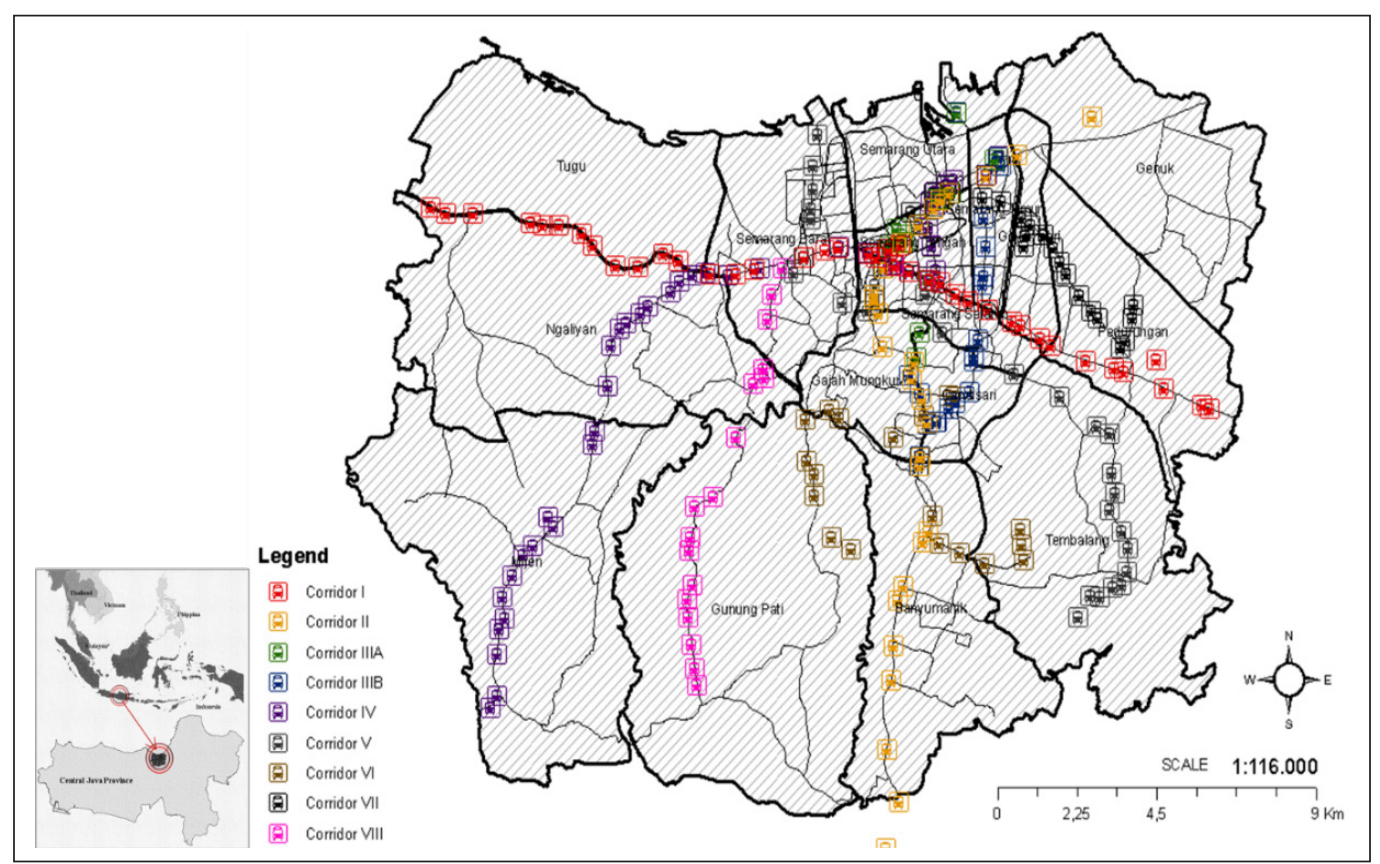

Figure 1. Bus Trans Semarang stops in the study area

Table 1

Bus Trans Semarang corridor profile

\begin{tabular}{|c|c|c|c|c|c|c|}
\hline \multirow[b]{2}{*}{ Corridor } & \multirow[b]{2}{*}{ Rute } & \multicolumn{3}{|c|}{ Number of } & \multirow{2}{*}{$\begin{array}{l}\text { Corridor } \\
\text { Length } \\
(\mathrm{Km})\end{array}$} & \multirow[b]{2}{*}{$\begin{array}{l}\text { Operating } \\
\text { Years }\end{array}$} \\
\hline & & $\begin{array}{c}\text { Pedestrian } \\
\text { (People) }\end{array}$ & $\begin{array}{l}\text { Bus } \\
\text { (Unit) }\end{array}$ & $\begin{array}{l}\text { Stops } \\
\text { (Unit) }\end{array}$ & & \\
\hline $\mathrm{I}^{*}$ & $\begin{array}{l}\text { Mangkang Terminal } \rightarrow \text { Penggaron } \\
\text { Terminal. }\end{array}$ & $2,713,852$ & 25 & 81 & 60.0 & 2009 \\
\hline II & Terboyo Terminal $\rightarrow$ Sisemut Terminal. & 838,081 & 34 & 74 & 26.5 & 2012 \\
\hline IIIA & $\begin{array}{l}\text { Tanjung Emas Port } \rightarrow \text { KagokTanjung } \\
\text { Emas Port. }\end{array}$ & 166,934 & 16 & 45 & 10.5 & 2014 \\
\hline IIIB & $\begin{array}{l}\text { Tanjung Emas Port } \rightarrow \text { Elizabeth } \\
\text { Hospital } \rightarrow \text { Tanjung Emas Port. }\end{array}$ & 111,289 & & 40 & 10.0 & 2014 \\
\hline IV & $\begin{array}{l}\text { Cangkiran Terminal } \rightarrow \text { Semarang } \\
\text { Tawang Station. }\end{array}$ & 520,436 & 22 & 87 & 22.3 & 2013 \\
\hline $\mathrm{V}$ & $\begin{array}{l}\text { Meteseh Residential } \\
\text { AreaAirport } \rightarrow \text { Marina Beach. }\end{array}$ & 366,319 & 16 & 75 & 25.9 & 2017 \\
\hline VI & $\begin{array}{l}\text { Diponegoro University } \rightarrow \text { Semarang } \\
\text { State University. }\end{array}$ & 257,831 & 16 & 63 & 13.4 & 2017 \\
\hline VII & $\begin{array}{l}\text { Terboyo Terminal } \rightarrow \text { Semarang City } \\
\text { Hall. }\end{array}$ & 87,886 & 13 & 63 & 6.9 & 2018 \\
\hline VIII & $\begin{array}{l}\text { Cangkiran Terminal } \rightarrow \text { Simpang Lima } \\
\text { (City Center). }\end{array}$ & 56,799 & 20 & 68 & 22.4 & 2019 \\
\hline
\end{tabular}

Note. * corridors with the most pedestrians 


\section{Quantitative Analysis}

This research utilized the quantitative research technique, which focused on analyzing the built environment in the form of density, diversity, and design. Data was collected through naturalistic direct field observation methods. Furthermore, the density analysis assessed the population frequency by comparing the total populace, using the interpolation method (ArcGIS 10.3). This analysis produced a spatial picture of population density in each Corridor. Also, the density component analysis used the numerical calculation method, such as the Floor Area Ratio (FAR), to compare the number of buildings per floor area. The calculations in accordance with Duduta's (2013) research, were divided into three categories, namely low (Equation 1), medium (Equation 2), and high (Equation 3) densities, as shown in Equation 1-3.

$$
\begin{aligned}
& \text { Low density } \quad=\frac{\text { number of buildings } 1-2 \text { floors }}{\text { the total number of buildings within a } 200 \text { meter radius of the stop point }} \\
& \text { Medium density }=\frac{\text { number of buildings } 3-8 \text { floors }}{\text { the total number of buildings within a } 200 \text { meter radius of the stop point }} \\
& \text { High density } \quad=\frac{\text { number of buildings }>8 \text { floors }}{\text { the total number of buildings within a } 200 \text { meter radius of the stop point }}
\end{aligned}
$$

Diversity components were analyzed, using the land-use ratio analysis, while comparing the residential, commercial, office space, public services, and recreational areas, to the total space around the Bus Trans Semarang bus-stop, in each Corridor. According to Sung et al. (2013), this diversity of land-use is used to compare the residential and non-residential areas, using the balancing index (RNR) formula, as shown in Equation 4.

$$
\mathrm{RNRi}=1-\left[\frac{\text { Res }- \text { Non res }}{\text { Res }+ \text { Non res }}\right] \rightarrow \text { The closer to } 1 \text {, the more balance }
$$

The design component was carried out by analyzing the road structure and pedestrian walkways' completeness features, based on movement needs. In this case, the assessment indicators were completeness elements, which include crossings, ramps, intersections, lane width, number of routes, and sidewalk furniture. The analysis of this component was presented to visualize the existing conditions, which were compared with the required pedestrian feature demand data, in Semarang. Further, the overall results of the density, diversity, and design analysis were processed, using the significance of linear regression (partial T-test) and the SPSS Statistics 24 application, to determine the effect of the built environment on walking activities in each Corridor. The model formula used in determining the influence between the variables is shown in Equation 5. 
$\mathrm{Y}=\mathrm{a}+\mathrm{b}(\mathrm{X})$

Where;

$\mathrm{Y}=$ frequency of pedestrians (person)

a $=$ constant

$\mathrm{b}=$ coefficient

$\mathrm{X}=$ built environment variables

Linear regression had been widely used in previous studies to produce a relationship model between the built environment variables and pedestrian movement patterns in an area. The requirements of linear regression analysis (partial T-test) is that when the results of the coefficients $(\mathrm{t})$ are greater than the t-table (2.35), with the regression data's significant value less than $0.05(<0.05)$, then both variables (dependent $\&$ independent), influences each other. The built environment variable consists of density (X1), diversity (X2), and design (X3) as independent variables, which correlates with the pedestrian intensity in each Corridor (Y), as shown in Figure 2.

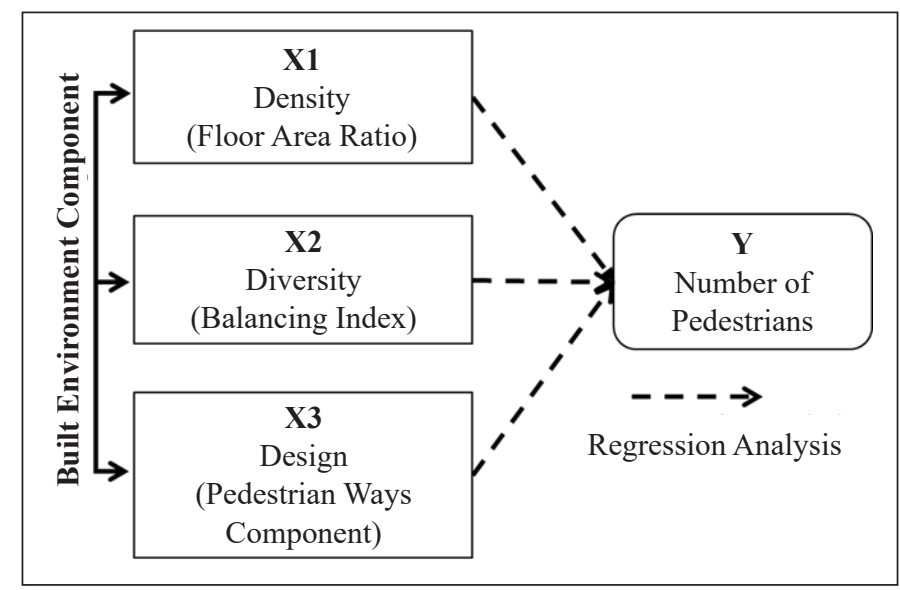

Figure 2. Linear regression analysis diagram

\section{RESULT AND DISCUSSION}

\section{Density Analysis}

Based on the comparative calculation between total population and land area in Semarang City, the highest population density was observed to occur in the downtown vicinity (Figure 3). This is similar to the theory of urban growth in the world, stating "the closer to the city centre, the higher the population density" (Fee \& Hartley, 2011). The high population density increases the demand for public transportation, including BRT, therefore, confirming the need to integrate services in areas with high density (Patankar et al., 2007). Figure 3 


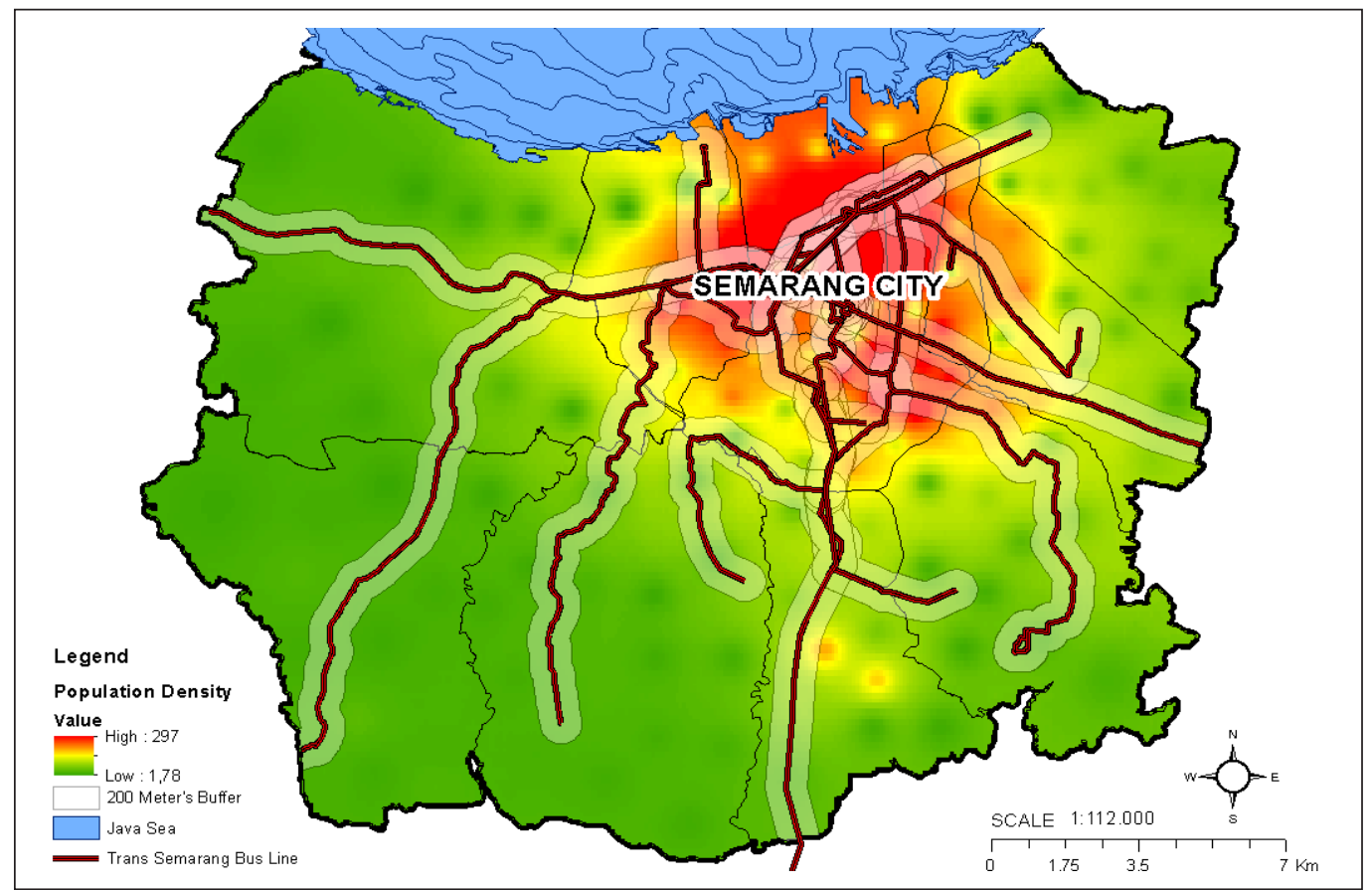

Figure 3: The population density in buffer area, 200 meters from bus corridor

shows the implementation of the Bus Trans Semarang system has paid attention to this theory, as observed in all routes (I-VIII) passing through the city centre and numerous bus-stops provided.

In addition to calculating population density, the component was measured by observing the quality of building. Table 2 shows the calculation of density values, with IIIB having the highest total, compared to other routes. The density in this corridor was dominated by $1-2$ floor buildings, indicated by the low frequency of 0.983 . Meanwhile, data from the observations showed the entire Bus Trans Semarang corridor were dominated by developments in a horizontal direction and following the road network. According to Table 2 , with regard to the element density conditions for each corridor, only three out of nine routes had a relatively high frequency value (33\%).

Furthermore, the research on transportation hubs in Japan discovered a high Floor Area Ratio (FAR) with optimized vertical building construction, improves land-use quality, while creating effective movement for pedestrians (Yang \& Yao, 2019). Thus, high density areas surrounded by vertical buildings, minimized the use of motorized vehicle and increased pedestrian intensity (Cervero \& Kockelman, 1997; Monteiro \& Campos, 2012; Zhang et al., 2016). Also, the density analysis along the Bus Trans Semarang corridor, produced results contrary to the study by Zhao et al. (2018), stating the dominance of density effect on the built environment and pedestrian activity in Beijing was high. This was in line with 
Table 2

The condition of the element density of all corridor radius 200 meters (Total)

\begin{tabular}{|c|c|c|c|c|c|c|c|c|c|c|}
\hline \multirow{3}{*}{ Corridor } & \multicolumn{4}{|c|}{ Building } & \multirow{3}{*}{$\begin{array}{l}\text { Lenght } \\
\text { of } \\
\text { corridor } \\
(\mathrm{Km})\end{array}$} & \multirow{3}{*}{$\begin{array}{c}\text { Large of } \\
\text { corridor (Ha) }\end{array}$} & \multirow{3}{*}{$\begin{array}{c}\text { Total } \\
\text { Density } \\
\text { (unit/ } \\
\text { Ha) }\end{array}$} & \multirow{2}{*}{\multicolumn{3}{|c|}{ Density }} \\
\hline & \multirow{2}{*}{$\begin{array}{c}1-2 \\
\text { floors } \\
\text { (unit) }\end{array}$} & \multirow{2}{*}{$\begin{array}{c}3-8 \\
\text { floors } \\
\text { (unit) }\end{array}$} & \multirow{2}{*}{$\begin{array}{c}>8 \\
\text { floors } \\
\text { (unit) }\end{array}$} & \multirow{2}{*}{$\begin{array}{l}\text { Total } \\
\text { (unit) }\end{array}$} & & & & & & \\
\hline & & & & & & & & Low & Medium & High \\
\hline (1) & (2) & (3) & (4) & $(5)$ & (6) & $200 *(6)=(7)$ & $(5) /(7)$ & $(2) /(5)$ & $(3) /(5)$ & $(4) /(5)$ \\
\hline I & 4,358 & 290 & 8 & 4,656 & 60.0 & 1,200 & 4 & 0.897 & 0.096 & 0.007 \\
\hline II & 3,833 & 130 & 3 & 3,966 & 26.5 & 530 & 7 & 0.960 & 0.043 & 0.001 \\
\hline IIIA & 3,258 & 84 & 6 & 3,348 & 10.5 & 210 & 16 & 0.958 & 0.039 & 0.003 \\
\hline IIIB* & 6,249 & 85 & 6 & 6,340 & 10.0 & 200 & 32 & 0.983 & 0.016 & 0.001 \\
\hline IV & 714 & 167 & 21 & 902 & 22.3 & 446 & 2 & 0.758 & 0.172 & 0.028 \\
\hline $\mathrm{V}$ & 968 & 152 & 18 & 1,138 & 25.9 & 518 & 2 & 0.817 & 0.164 & 0.039 \\
\hline VI & 3,587 & 121 & 0 & 3,708 & 13.4 & 268 & 14 & 0.936 & 0.064 & 0.000 \\
\hline VII & 654 & 110 & 2 & 766 & 6.9 & 138 & 6 & 0.824 & 0.149 & 0.002 \\
\hline VIII & 171 & 96 & 7 & 274 & 22.4 & 448 & 1 & 0.632 & 0.341 & 0.027 \\
\hline
\end{tabular}

Note. * corridor with the highest density

the Chinese government's regulation of intensifying vertical development, to implement a sustainable city development, and is different from the existing regulation condition in Semarang, with no emphasis on vertical building. However, increased vertical building growth is required, especially in downtown areas, in terms of land-use optimization, with the creation of a pedestrian-friendly and sustainable transit-based transportation system.

\section{Diversity Analysis}

Table 3 shows the equilibrium calculation results, with the total balance index of all the corridors close to 1 , thus, categorized as areas with mixed land-use, possessing high parameters (Sung et al., 2013). Furthermore, the highest balancing index of 1.110, was obtained in the Corridor II area, with trade and service centre as the mainland-use. The area's function as a centre for trade and services, has led to increasingly diverse land-use, and the proportion of residential (60 hectares) to non-residential (59 hectares) land in the area is very stable within a $200 \mathrm{~m}$ radius, from the transit centre. As one of the longest routes, Corridor I had the smallest balancing index of 0.395 (getting away from 1). In this corridor, the proportion of residential to non-residential land-use area is unbalanced. The residential land amounts to $98.70 \mathrm{ha}$, while non-residential areas dominated by trade and services, offices, and industry, was only 40.22ha.

In addition to the total calculation results, the table above also explains the stop points with the highest balancing index value on each route. This aims to serve as the main sample, showing the spatial balancing index conditions through land use, per building. In general, Figure 4 explains the position of the balancing index sample point for each 
Table 3

Condition element diversity for all corridor radius 200 meters (Total)

\begin{tabular}{|c|c|c|c|c|}
\hline \multirow[t]{2}{*}{ Corridor } & $\begin{array}{l}\text { Res } \\
(\mathrm{Ha})\end{array}$ & $\begin{array}{l}\text { Non-res } \\
\text { (Ha) }\end{array}$ & $\begin{array}{l}\text { Balancing } \\
\text { Index }\end{array}$ & Landuse \\
\hline & $(1)$ & $(2)$ & $(1) /(2)=(3)$ & (4) \\
\hline $\mathrm{I}^{* *}$ & 98.70 & 40.22 & 0.395 & $\begin{array}{l}\text { Settlements, industry, trade and services, warehousing, } \\
\text { worship, defense and security, offices, education, health, } \\
\text { recreation, public spaces, sports. }\end{array}$ \\
\hline II* & 60.59 & 58.72 & 1.110 & $\begin{array}{l}\text { Offices, trade and services, police education and sports, } \\
\text { industry, and housing. }\end{array}$ \\
\hline IIIA & 64.58 & 89.44 & 0.831 & Defense and security, education, health, offices, public \\
\hline IIIB & 56.55 & 23.04 & 1.184 & $\begin{array}{l}\text { spaces, recreation, settlements, trade and services, and } \\
\text { worship. }\end{array}$ \\
\hline IV & 261.32 & 339.46 & 0.870 & $\begin{array}{l}\text { Offices, worship, health, trade and services, education, } \\
\text { housing, recreation, defense and security, and } \\
\text { transportation. }\end{array}$ \\
\hline $\mathrm{V}$ & 215.86 & 311.21 & 0.820 & $\begin{array}{l}\text { Education, health, industry, offices, defense and security, } \\
\text { housing, sports, recreation, trade and services, and worship. }\end{array}$ \\
\hline VI & 57.68 & 31.10 & 1.314 & $\begin{array}{l}\text { Defense and security, education, health, offices, settlements, } \\
\text { recreation, trade and services, and worship. }\end{array}$ \\
\hline VII & 129.01 & 247.47 & 0.685 & $\begin{array}{l}\text { Education, health, industry, offices, defense and security, } \\
\text { housing, sports, recreation, trade and services, and worship. }\end{array}$ \\
\hline VIII & 158.80 & 167.19 & 0.938 & $\begin{array}{l}\text { Trade and services, worship, health, education, offices, } \\
\text { recreation, defense and security, and settlements. }\end{array}$ \\
\hline
\end{tabular}

Note. Res (Rsidential area), Non-res (Non-residential area): *corridor with the highest balancing index; ** corridor with the lowest balancing index

corridor on the distribution of land use in Semarang City. Meanwhile, Figure 5, section $\mathrm{H}$ shows the location of the highest balancing index for Corridor I is the same with VIII, at the Amarta bus-stop point, with a value of 1.10, and dominated by non-residential land-use, including trade and services. Meanwhile, Figure 5, section A show the location with the highest balancing index for Corridor II area is the City Hall bus-stop, with a value of 0.96, and dominated by non-residential land-use, in the form of offices as well as educational buildings. Figure 5, section $\mathrm{B}$ shows the location with the highest balancing index on Corridor IIIA is the Raden Patah bus-stop point, with a value of 1.06, and dominated by non-residential land-use in the form of trade as well as services, with school buildings. However, Figure 5, section $\mathrm{C}$ shows the highest balancing index for Corridor IIIB was located at the Don Bosco stopping point, with a value of 1.06 , and dominated by residential land use, including housing and school buildings.

Furthermore, Figure 5, section D shows the location with the highest balancing index in the Corridor IV area is Nyaliyan Square bus-stop, with a value of 0.99, and dominated by non-residential land use, in the form of trade as well as services, with educational buildings. Meanwhile, Figure 5, section E shows the highest balancing index in Corridor 


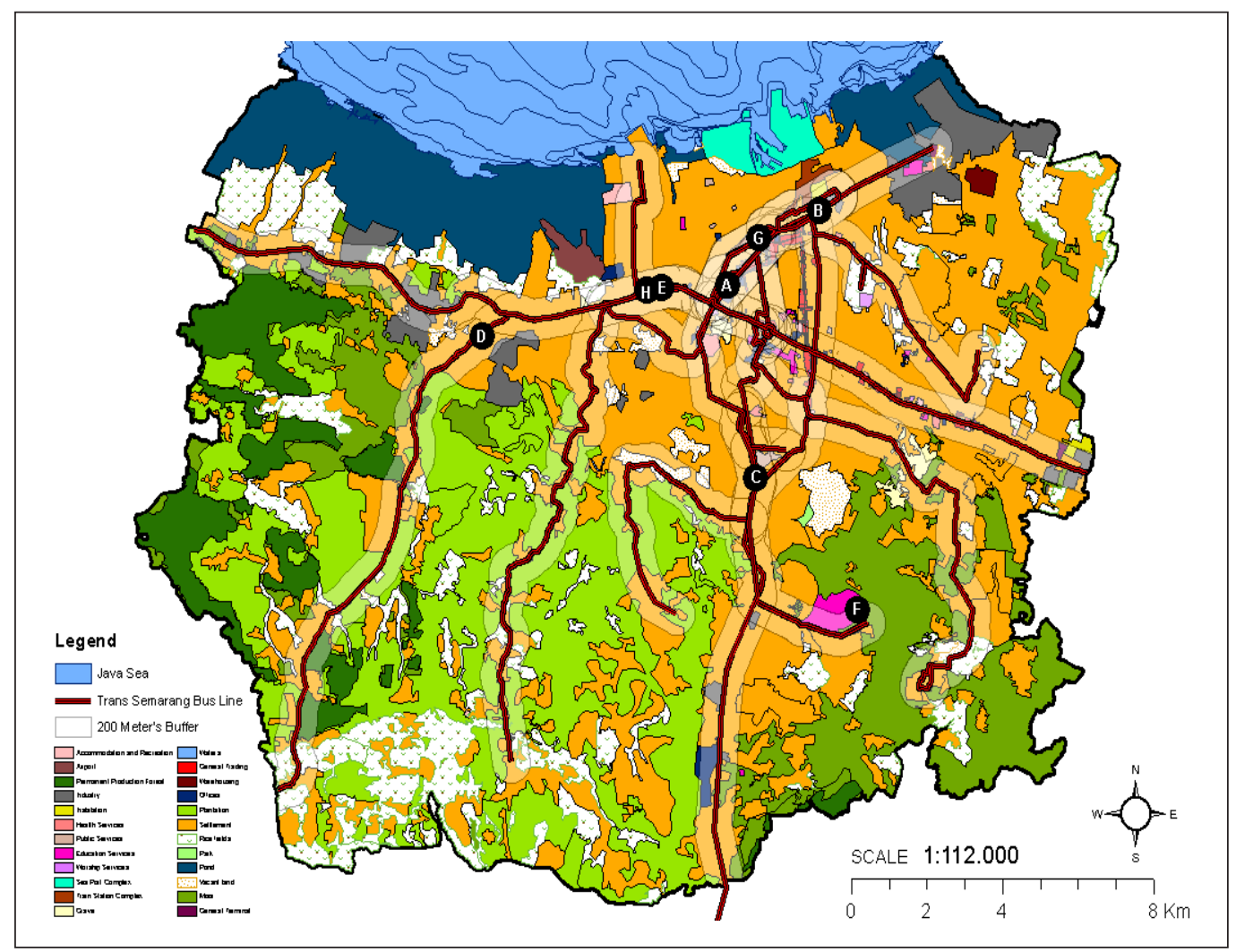

Figure 4.The distribution of land use and location of balancing index sample points in Semarang City

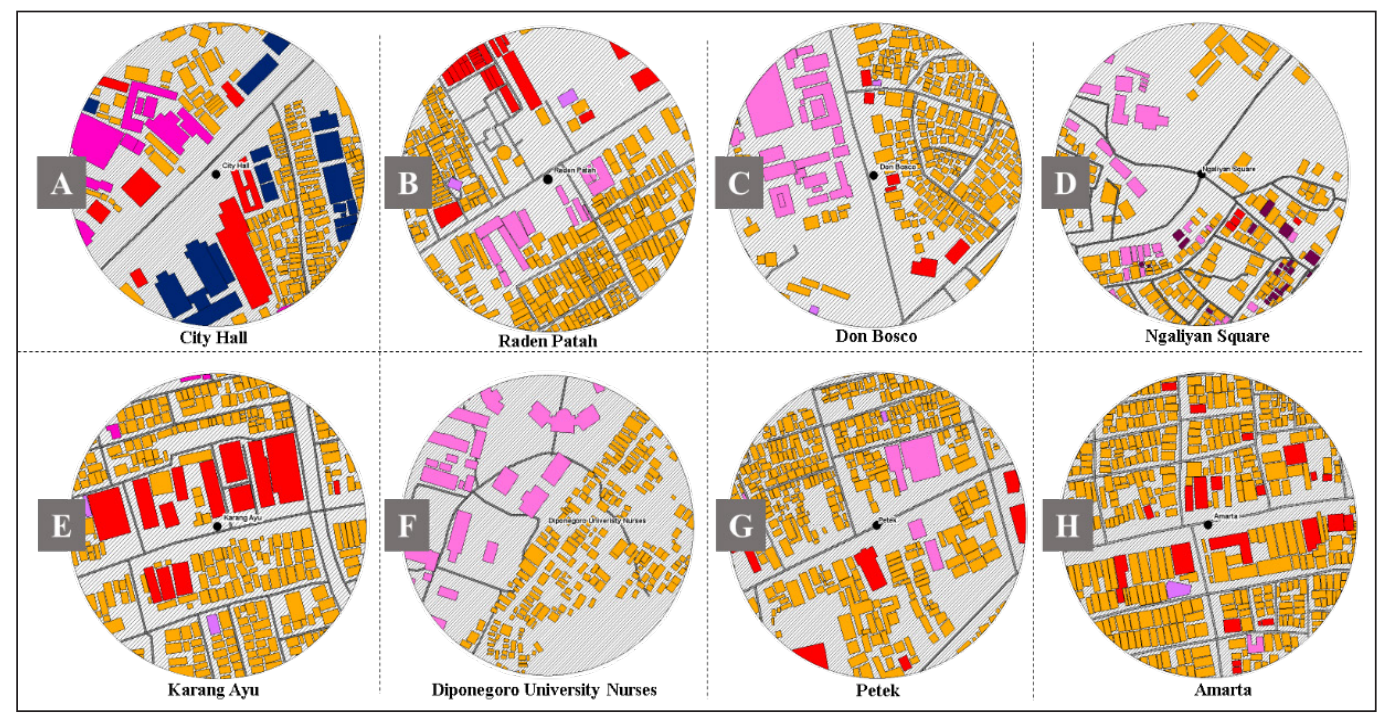

Figure 5. The land use corridor and highest balancing index value (200 meters) ; (A) Corridor II, (B) Corridor IIIA, (C) Corridor IIIB, (D) Corridor IV, (E) Corridor V, (F) Corridor VI, (G) Corridor VII, (H) Corridor I \& VIII. 
$\mathrm{V}$ area, is located at the Karang Ayu bus-stop, with a value of 1.00 (very balanced), and dominated by settlement land-use. Figure 5, section F shows the highest balancing index value in Corridor VI, is located at the Diponegoro University Nursing bus-stop (educational area), with a value of 1.04, and dominated by non-residential land-use, in the form of educational buildings. Meanwhile in Figure 5 section $\mathrm{G}$, shows the the highest balancing index in Corridor VII is at the Petek bus-stop point, with a value of 0.99 , and dominated by non-residential land use, in the form of trade as well as services.

The diversity analysis results for all Bus Trans Semarang corridors had the same pattern of balance index. In addition, locations with the highest balancing index, were dominated by land-use for education, trade, and services. Several studies stated commercial land-uses (educational with trade and services) were able to increase people's interest in walking activity, within the area (Miranda-Morenoa et al., 2011; Townsend \& Zacharias, 2010; Chalermpong, 2007). Based on field observations, activities in the area of education, trade and services are conducted only at morning as well as evening, especially on weekdays (Monday-Friday), and pedestrian walkways are rarely used during holidays. In addition, an increase in attractions is required to bring in and improve activities, thus, allowing public facilities, including pedestrian walkway, to function optimally. According to Untermann and Lynn (1984), areas with mixed land-use characteristics on foot are more attractive, because the resulting movements are more diverse. Therefore, various types of land-use are required to improve population activities' pattern, consequently, optimizing the usage of space and creating a sustainable pedestrian walkways system.

\section{Design Analysis}

The pedestrian walkways design analysis showed Corridors IV, I, and II are routes with the highest number of inclines, crossings, and irregularities in comparison with the others as indicated in Table 4. Moreover, a linear pattern is produced towards the pedestrian walkway facilities when compared with the data presented in Table 1 and the corridors with the highest number of pedestrians were observed to have the tendency of having more complete facilities. It was also discovered that the closeness to the city center where there is a denser population activity level leads to a better and more complete walkway facilities design. Meanwhile, some locations observed to be far from the city center such as those traversed by Corridor VI have pedestrian walkways with a width of $1 \mathrm{~m}-2 \mathrm{~m}$ and are only equipped with vegetations as shown in Table 4 and Figure 6.

The sidewalks along the Bus Trans Semarang corridor needs improvement due to the differences observed between the current condition and user needs. The region's undulating topography and climatic conditions makes the average walking distance in Semarang City to be only $200 \mathrm{~m}-250 \mathrm{~m}$. Therefore, the completeness of the design components and city environmental conditions for the pedestrian walkways has the ability to increase people's 
Table 4

Complete pedestrian walkways design for the Bus Trans Semarang corridor radius 200 meters (Total)

\begin{tabular}{|c|c|c|c|c|c|c|}
\hline \multirow[b]{2}{*}{ Corridor } & \multirow{2}{*}{$\begin{array}{l}\text { Pedestrian } \\
\text { walkways } \\
\text { Large }(\mathrm{m})\end{array}$} & \multirow{2}{*}{$\begin{array}{l}\text { Lanes } \\
\text { of the } \\
\text { road }\end{array}$} & \multicolumn{3}{|c|}{ Number of } & \multirow[b]{2}{*}{ Street Furniture } \\
\hline & & & $\begin{array}{c}\text { Inter } \\
\text { sections }\end{array}$ & Ramp & Crossings & \\
\hline$I^{*}$ & $1-5$ & $2-6$ & 172 & 267 & 42 & $\begin{array}{l}\text { Shade vegetation, bollards, lights, trash } \\
\text { cans, traffic signs, seats, special lanes for } \\
\text { the disabled. }\end{array}$ \\
\hline II* & $1-5$ & 2 & 165 & 138 & 38 & $\begin{array}{l}\text { Traffic signs (no stopping sign, no } \\
\text { parking), street lights, ways with } \\
\text { disabilities, and potted vegetation. }\end{array}$ \\
\hline IIIA & $1-5$ & $1-2$ & 95 & 3 & 13 & $\begin{array}{l}\text { Lights, bollards, vegetation, traffic signs, } \\
\text { trash cans, fire hydrants. }\end{array}$ \\
\hline IIIB & $1-1.5$ & $1-2$ & 246 & 0 & 22 & Shade vegetation, and traffic signs. \\
\hline $\mathrm{IV}^{*}$ & $1-3$ & $2-4$ & 110 & 396 & 30 & $\begin{array}{l}\text { Shade vegetation, bollards, lights, traffic } \\
\text { signs, and special lanes for the disabled. }\end{array}$ \\
\hline $\mathrm{V}$ & $0.5-2.5$ & $1-2$ & 170 & 27 & 31 & $\begin{array}{l}\text { Shade vegetation, lights, traffic signs, } \\
\text { benches, and special lanes for people with } \\
\text { disabilities. }\end{array}$ \\
\hline VI & $1-3$ & 2 & 132 & 40 & 18 & Traffic lights and signs. \\
\hline VII & $1-2.5$ & $1-2$ & 127 & 21 & 12 & $\begin{array}{l}\text { Shade vegetation, lights, traffic signs, and } \\
\text { ways for the disabled. }\end{array}$ \\
\hline VIII & $1-3$ & $2-6$ & 24 & 184 & 16 & $\begin{array}{l}\text { Shade vegetation, special lanes for people } \\
\text { with disabilities, and traffic signs. }\end{array}$ \\
\hline
\end{tabular}

Note. corridor with the most complete design elements

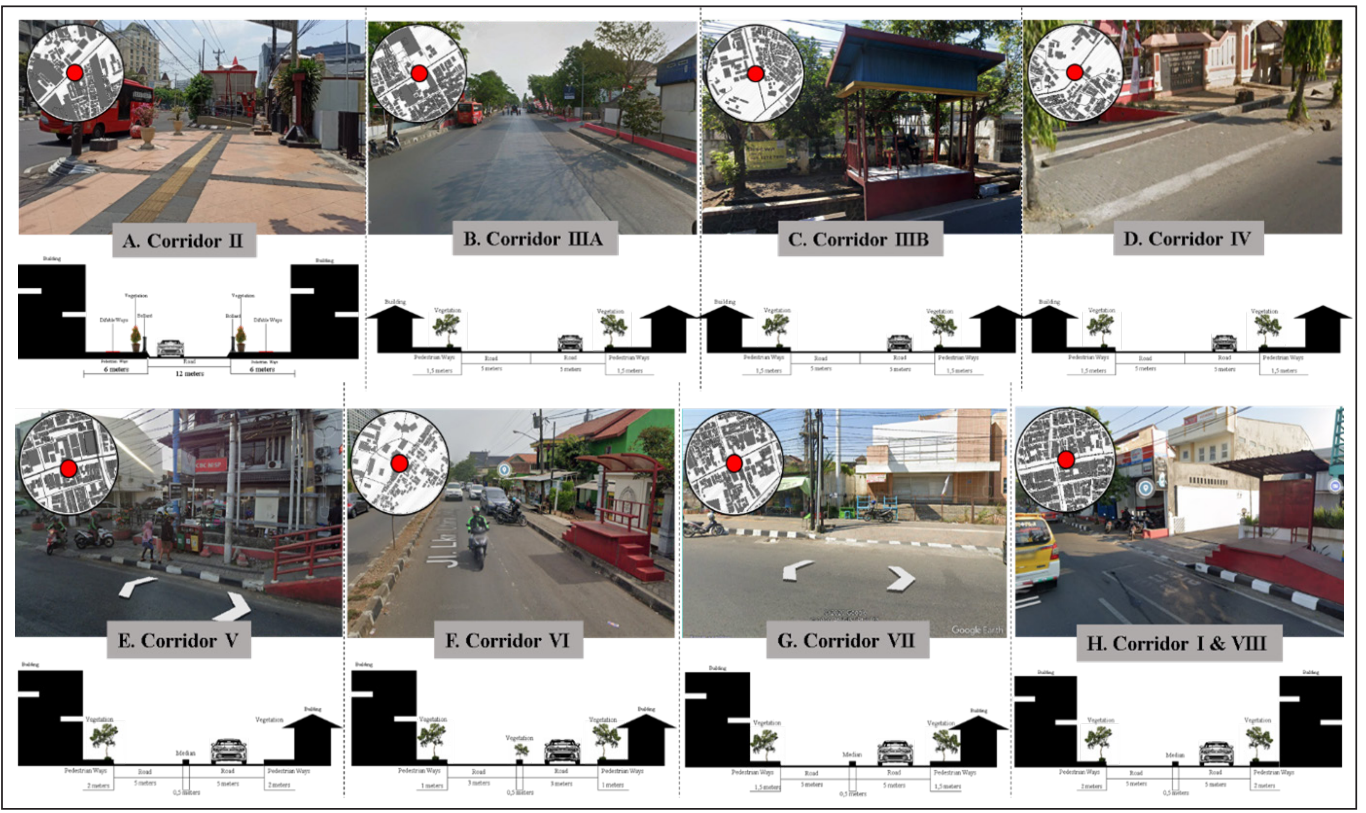

Figure 6. Pedestrian walkways conditions throughout the Bus Trans Semarang corridor. Sample of pedestrian walkways for corridor II, IIIA, IIIB, IV, V, VI, VII, and VIII. 
willingness to walk to and from a destination (Özbil et al., 2015). It has also been reported that completed facilities such as ramps, sidewalks, vegetation, and several others affect walking activities in the area (Dixon, 1996; Munshi, 2016). However, the country has a tropical climate and year-round sunshine which causes some level of discomfort in engaging in outdoor activities such as walking. This means there is a need for adjustment based on the climate by using vegetation as shade which has been reported to be applicable in four-seasoned countries as observed in Montreal, Canada (Miranda-Morenoa et al., 2011). This vegetation also has the ability to produce sufficient oxygen and reduce carbon dioxide from motorized pollution at the same time. This, therefore, means it is necessary to have a pedestrian walkway with complete facilities and focus on both environmental and climatic conditions in order to achieve a sustainable transportation system.

\section{The Built Environment Model Affecting Pedestrians}

The linear regression test conducted using the partial coefficient T-test method was used to determine the significance of the relationship between two or more variables. This involves the application of two things which are the coefficient $T$ and the significant results as the benchmarks. The number of pedestrian passengers at the Bus Trans Semarang per corridor (Y) was used as the dependent variable while the built environment which included the total density (X1), balancing index diversity (X2), and the number of walkway design elements (X3) in a radius of 200 from corridors were used as the independent variables. The results presented in Table 5 showed the T-value of density (X1) is 0.454 with a significance value of $0.669(>0.05)$ and this means this variable did not significantly influence the pedestrian intensity (Y) due to the fact that the calculated T-value was lesser than the T-table value of 2.353 while the significance is greater than 0.05 .

The table also shows diversity (X2) had a coefficient T-value of $7.028(>2.353)$ with a significance calculated value of $0.001(<0.05)$ and this means there is a significant relationship between the pedestrian intensity (Y) and diversity (X2). This shows that

Table 5

The results of data processing linear regression (partial T-test) SPSS

\begin{tabular}{llccc}
\hline Code & Independent Variable & $\begin{array}{c}\text { Unstandardized } \\
\text { B }\end{array}$ & T* & Sig** \\
\hline Coefficient & & 2.630 & & \\
X1 & Density (Floor Area Ratio calculation) & 0.011 & 0.454 & 0.669 \\
X2 & $\begin{array}{l}\text { Diversity (The ratio of residential and non-residential } \\
\text { land or Balancing Index) }\end{array}$ & 2.172 & 7.028 & 0.001 \\
X3 & $\begin{array}{l}\text { Design (The completeness of the pedestrian } \\
\text { walkway elements) }\end{array}$ & 0.000 & 1.624 & 0.165 \\
\hline
\end{tabular}

Note. The F table value is $2.35:{ }^{*}$ If $\mathrm{T}$ count $>\mathrm{T}$ the data table has a close relationship; ${ }^{*}$ Sig $<0.05$ has a significant relationship meaning 
diversity has a positive influence on the intensity of pedestrians at the research location and this is reflected in the more balanced use of land in some areas which led to a higher frequency of people taking a walk. Moreover, design (X3) was found not to have a significant relationship with the pedestrian intensity (Y) as observed in the smaller calculated T-value of 1.624 in comparison with the 2.353 recorded on the T-table with the significance calculated also indicated to be greater than the standard of tolerance $(>0.05)$.

The linear regression model in Equation 6 showed the diversity variable had a positive effect on the frequency of pedestrians as indicated by the higher level of balancing index in an area which led to an increase in the number of pedestrians. However, when the probability of diversity or balancing index increased by 2.172 , the frequency of pedestrians was observed to have risen by 2.630 million in a year as indicated in Equation 6 .

$$
\mathrm{Y}=2.630+2.172 \times 2
$$

These results are similar to the findings of the research conducted in the City of Montreal, Canada where land diversity was reported to be influencing the tendency of a person to walk around the transit center (Miranda-Morenoa et al., 2011). The land designed for trade and services with school buildings were found to have the highest pedestrian movements. Moreover, a study in Bangkok also showed commercial land tends to encourage people to walk around transit centers (Townsend \& Zacharias, 2010; Chalermpong, 2007). The environmental conditions along the transit-based transportation routes in Bangkok City have been observed to have the closest characteristics to the area studied in this present research. This involved the relative spreading out of the building density and land-use from the city center to the suburbs as well as the non-optimal facilities provided for the pedestrian walkways. Meanwhile, the differences observed are focused on the research area coverage, topographical conditions, and urban development policies. For example, the density of Montreal and Beijing tends to influence people to walk frequently due to their flat topography, vertical development policies, and the relatively close distance between buildings and transit centers. The pedestrian design elements in Montreal are also relatively complete when compared to Semarang and Bangkok City of Thailand. The model produced from the analysis is, however, presented in the following Figure 7.

\section{CONCLUSION}

The analysis showed the diversity component is an important feature of the built environment which significantly influences how frequent people walk along the Bus Trans Semarang. This was indicated by a high balancing index between residential and non-residential land-uses with the commercial lands dominated by activities in the form of trade, education, and service areas. Furthermore, the high mixed use of land areas tends 


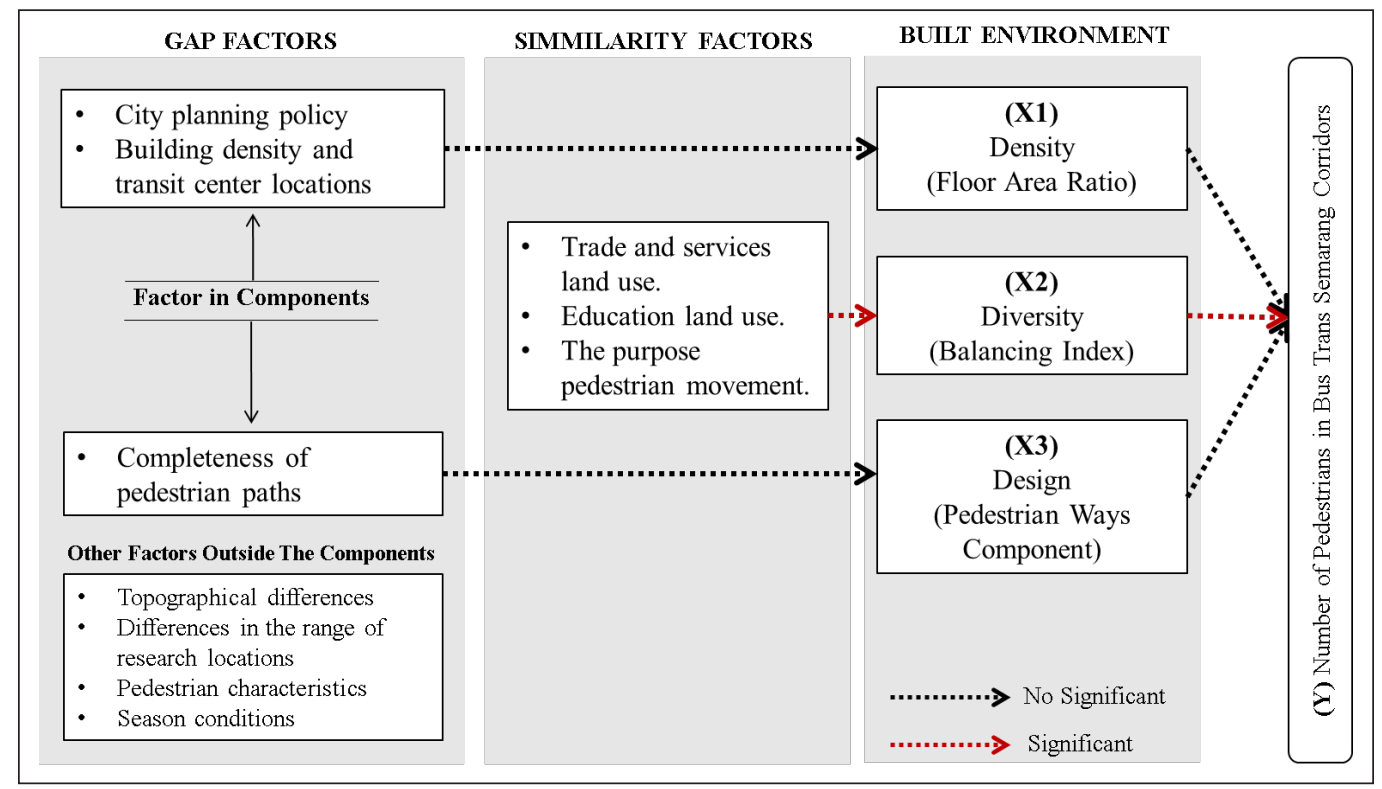

Figure 7. Model for the influence of built environment on pedestrian activity

to affect people's frequency to walk due to the diversity in their patterns of activity. The model also showed the existence of a positive relationship between the diversity variable and the frequency of pedestrians and this further indicates the ability of a higher level of balancing index to increase the frequency of pedestrians in the study area.

The two other components including density and design were, however, observed not to have any effect on how frequent people walk. Moreover, the distance between the buildings tends to be far apart due to the very minimal optimization of vertical development. The lack of pedestrian facilities along the Bus Trans Semarang corridor, especially in the city center area, is discovered to be part of the reasons the components did not have influence on the frequency to walk in the city of Semarang. There is also the fear to avoid the effect of this issue on people's desire to use transit-based transportation such as the Bus Trans Semarang. Therefore, a follow-up measure is expected to be made available to adjust pedestrians' demands to the built environment in order to create a sustainable transportation system.

\section{ACKNOWLEDGEMENTS}

The authors are grateful to the Directorate of Research and Community Service, Deputy of Strengthening Research and Development of the Ministry of Technology/National Research, and the Innovation Agency of the Republic of Indonesia, (2020 fiscal year) for funding this research. 


\section{REFERENCES}

Blanco, H., \& Alberti, M. (2009). Hot, congested, crowded and diverse: emerging research agendas in planning. Progress in Planning, 71(4), 153-205. https://doi.org/10.1016/j.progress.2009.03.001

Cervero, R., \& Kockelman, K. (1997). Travel demand and the 3Ds: Density, diversity, and design. Transportation Research part D: Transport and Environment, 2(3), 199-219. https://doi.org/10.1016/ S1361-9209(97)00009-6

Chalermpong, S. (2007). Rail transit and residential land use in developing countries: Hedonic study of residential property prices in Bangkok, Thailand. Transportation Research Record, 2038(1), 111-119. https://doi.org/10.3141/2038-15

Dixon, L. B. (1996). Bicycle and pedestrian level-of-service performance measures and standards for congestion management systems. Transportation Research Record, 1538(1), 1-9. https://doi.org/10.1177/0361198 196153800101

Duduta, N. (2013). Direct ridership models of bus rapid transit and metro systems in Mexico City. Transportation Research Board, 2394(1), 93-99. https://doi.org/10.3141/2394-12

Fee, K., \& Hartley, D. (2011). Urban growth and decline: The role of population density at the city core. Federal Reserve Bank of Cleveland.

Hu, J. H., Zhan, C. Z., Cheng, Z. F., \& Wang, B. (2013). A research of pedestrian evacuation simulation for BRT station based on fine grid method. Procedia Engineering, 52, 137-144. https://doi.org/10.1016/j. proeng.2013.02.118

ITDP. (2017). The BRT standard 2016. Institute for Transportation \& Development Policy Indonesia.

Kim, C., Parent, O., \& Hofe, R. V. (2018). The role of peer effects and the built environment on individual travel behavior. Environment and Planning B: Urban Analytics and City Science, 45(3), 452-469. https:// doi.org/10.1177/2399808317740354

Makarova, I., Pashkevich, A., Shubenkova, K., \& Mukhametdinov, E. (2017). Ways to increase population mobility through the transition to sustainable transport. Procedia Engineering, 187, 756-762. https://doi. org/10.1016/j.proeng.2017.04.434

Miranda-Morenoa, L. F., Morency, P., \& El-Geneidy, A. M. (2011). The link between built environment, pedestrian activity and pedestrian-vehicle collision occurrence at signalized intersections. Accident Analysis and Prevention, 43(5), 1624-1634. https://doi.org/10.1016/j.aap.2011.02.005

Monteiro, F. B., \& Campos, V. B. G. (2012). A proposal of indicators for evaluation of the urban space for pedestrians and cyclists in access to mass transit station. Procedia - Social and Behavioral Sciences, 54, 637-645. https://doi.org/10.1016/j.sbspro.2012.09.781

Munshi, T. (2016). Built environment and mode choice relationship for commute travel in the city of Rajkot, India. Transportation Research Part D, 44, 239-253. https://doi.org/10.1016/j.trd.2015.12.005

Oktaviani, I., Dewi, D. I. K., \& Rakhmatulloh, A. R. (2020). Can building density influence the amount of BRT trans Semarang ridership? In IOP Conference Series: Earth and Environmental Science (Vol. 409, No. 1, p. 012038). IOP Publishing. https://doi.org/10.1088/1755-1315/409/1/012038 
Özbil, A., Yeşiltepe, D., \& Argin, G. (2015). Modeling walkability: The effects of street design, street-network configuration and land-use on pedestrian movement. Journal of the Faculty of Architecture, 12(3), 189-207.

Patankar, V. M., Kumar, R., \& Tiwar, G. (2007). Impacts of bus rapid transit lanes on traffic and commuter mobility. Journal of Urban Planning and Development, 133(2), 99-106. https://doi.org/10.1061/ (ASCE)0733-9488(2007)133:2(99)

Purwanto, E., \& Manullang, O. R. (2018). Evaluasi trotoar sebagai feeder non motorized untuk mendukung bus rapid transit (BRT) di Kota Semarang [Evaluation of sidewalk as a non motorized feeder to support bus rapid transit (BRT) in Semarang City]. Jurnal Pembangunan Wilayah dan Kota, 14(1), 17-27. https:// doi.org/10.14710/pwk.v14i1.17336

SuaraMerdeka. (2015, October 09). Trans Semarang jadi percontohan [Trans Semarang Becomes Pilot]. Suara Merdeka. Retrieved October 20, 2015, from https://www.suaramerdeka.com/

Sung, H., Go, D., \& Choi, C. G. (2013). Evidence of Jacobs's street life in the great Seoul city: Identifying the association of physical environment with walking activity on streets. Cities, 35, 164-173. https://doi. org/10.1016/j.cities.2013.07.010

Timmermans, H. (Ed.). (2009). Pedestrian behaviour: Models, data collection and application. Emerald Group Publishing Limited.

Townsend, C., \& Zacharias, J. (2010). Built environment and pedestrian behavior at rail rapid transit stations in Bangkok. Transportation, 37(2), 317-330. https://doi.org/10.1007/s11116-009-9226-8

Untermann, R. K., \& Lynn, L. (1984). Accommodating the pedestrian: Adapting towns and neighborhoods for walking and bicycling. Van Nostrand Reinhold.

Yang, C., \& Yao, M. (2019). Ultra-high intensity redevelopment of the core area of Japanese rail transit hub station. International Journal of Sustainability and Planning, 14(3), 245-259. https://doi.org/10.2495/ SDP-V14-N3-245-259

Zhang, Y., Ding, C., \& Huang, L. (2016). the built environment and the frequency of cycling trips by Urban elderly: Insights from Zhongshan, China. Journal of Asian Architecture and Building Engineering, 15(3), 511-518. http://doi.org/10.3130/jaabe.15.511

Zhao, C., Nielsen, T. A. S., Olafsson, A. S., Carstensen, T. A., \& Meng, X. (2018). Urban form, demographic and socio-economic correlates of walking, cycling, and e-biking: Evidence from eight neighborhoods in Beijing. Transport Policy, 64, 102-112. https://doi.org/10.1016/j.tranpol.2018.01.018 
